\title{
Community based aquaculture in the western Indian Ocean: challenges and opportunities for developing sustainable coastal livelihoods
}

\author{
Mebrahtu Ateweberhan $^{1}, \underline{\text { Joanna Hudson }}^{1}$, Antoine Rougier $^{1}, \underline{\text { Narriman S. Jiddawi }}^{2}$, Flower E. Msuva $^{2,3}$ Selina M. Stead $^{4}$ \\ and Alasdair Harris ${ }^{1}$
}

\begin{abstract}
The small-fisheries social-ecological system in the western Indian Ocean (WIO) represents a typical social-ecological trap setting where very poor natural resources dependent coastal communities face local and global threats and engage in unsustainable practices of exploiting limited resources. Community-based aquaculture (CBA) has been implemented as an important alternative or supplementary income generating activity for minimizing the overdependence on marine natural resources and promoting biodiversity conservation. Despite its proliferation throughout the WIO region in recent decades, little is known about the degree to which CBA activities have contributed to achieving the objectives of breaking the cycle of poverty and environmental degradation and promoting community development and biodiversity conservation. In order to improve understanding of common challenges and to generate recommendations for best practice, we assessed the most common CBA activities practiced in the region through literature review and workshop discussion involving practitioners and key stakeholders. Findings indicated that despite favorable environmental conditions for various CBA practices, the sector remains underdeveloped, with few activities delivering the intended benefits for coastal livelihoods or conservation. Constraints included a shortage of seed and feed supplies, low investment, limited technical capacity and skills, insufficient political support, and lack of a clear strategy for aquaculture development. These are compounded by a lack of engagement of local stakeholders, with decision making often dominated by donors, development agencies, and private sector partners. Many of the region's CBA projects are designed along unrealistically short time frames, driven by donors rather than entrepreneurs, and so are unable to achieve financial sustainability, which limits the opportunity for capacity building and longer-term development. There is little or no monitoring on ecological and socioeconomic impacts. Except for a few isolated cases, links between CBA and marine conservation outcomes have rarely been demonstrated. Realizing the potential of CBA in contributing toward food security in the WIO will necessitate concerted investment and capacity strengthening to overcome these systemic challenges in the sector. Lessons herein offer managers, scientists, and policy advisors guidance on addressing the challenges faced in building strategic development initiatives around aquaculture in developing countries.
\end{abstract}

Key Words: community-based conservation; ecosystem services; marine reserves; participatory approach; private-public-partnerships; propoor approaches; small-scale fishing; social-ecological trap; sustainable development

\section{INTRODUCTION}

Community-based aquaculture (CBA) is increasingly being proposed as an alternative or supplementary income-generating activity aimed at improving livelihoods and food security of poor coastal communities (Ireland et al. 2004, Gonzales et al. 2006, Allison 2011, Beveridge et al. 2013). When successful, it can be beneficial in reducing dependence on natural resources, and may in turn promote biodiversity conservation by reducing fishing pressures on marine ecosystems (Brummett et al. 2008, Diana 2009, Little et al. 2012, Troell et al. 2014). By diversifying coastal livelihoods, providing new skills, and improving participation and empowerment, CBA has also the potential to improve local economies and enhance food security, strengthening communities' adaptive capacity to climate change and other environmental threats (Troell et al. 2011, Béné et al. 2016, Gentry et al. 2017).

The coastal communities of the western Indian Ocean (WIO) region are among the poorest in the world, as well as within their respective countries (Mirera and Samoilys 2008, Cinner 2009, 2011, Anderson and Saidi 2011, Cinner et al. 2012). They have low levels of education and technical skills and are largely marginalized within coastal states, with no formal rights to the marine resources on which they depend. Many of them rely heavily on harvesting marine resources for their livelihoods (Van der Elst et al. 2005, Loper et al. 2008, Cinner 2009, Barnes-Mauthe et al. 2013). The coastal ecosystems in the region have suffered from habitat degradation, associated with direct human activities including overfishing, pollution, unsustainable coastal development, as well as stresses associated with recent extreme thermal events (McClanahan et al. 2008, Harris et al. 2010, Cinner et al. 2012). Considering the predicted population increase in the region (Bradshaw and Brook 2014) and the rise in frequency of extreme climatic disturbances, the trend is expected to continue (Christensen et al. 2007, McClanahan et al. 2007, Maina et al. 2008), further undermining the integrity of marine ecosystems and associated ecosystem services. The social-ecological systems in the region have been described as a typical social-ecological trap situation, where very poor local communities dependent on natural resources face local threats and global pressures and engage in overharvesting and destructive practices (Cinner 2011). The capacity of the natural systems to function optimally, bounce from natural and man-made disturbances, and provide adequate ecosystem services has been reduced, further increasing vulnerability of local communities.

Aimed at improving livelihoods of these poor coastal communities and/or promoting conservation of the marine biodiversity through creation of marine reserves and alleviating 
fishing pressure, CBA projects have been developed in many parts of the WIO in the last two decades. Diverse product species are farmed, employing a wide range of techniques and production models and partnerships (Box 1). The rise of CBA initiatives in the WIO has resulted in a dynamic and cross-cutting sector, involving local communities, research institutions, NGOs, and business partnerships in a broad range of scientific, technical, and business disciplines (Troell et al. 2011, Slater et al. 2013). Several reviews exist on aquaculture in the WIO in general, its benefits and drawbacks, and the main challenges for its sustainability (Dadzie 1992, Bryceson 2002, Rönnbäck et al. 2002, Rice et al. 2006, Shoko et al. 2011, Troell et al. 2011). Nevertheless, there are not many that specifically address community-based approaches, whose characteristics are generally very different to large-scale enterprises. The few publications that provide reviews on CBA address particular types, e.g., milkfish (Chanos chanos) farming in Kenya (Mirera and Ngugi 2009), seaweed farming in Zanzibar (Eklöf et al. 2012), and sea cucumber farming in the WIO (Eriksson et al. 2012), underlying the need for a comprehensive review of the sector.

This paper presents results of an international expert-led workshop conducted in Zanzibar in 2013 whose aim was to identify the main challenges faced by CBA projects in the WIO and to provide useful information for promoting profitable and sustainable CBA. Despite their many unique characteristics, like any commercial operation, the market-oriented nature of CBA initiatives may bring about conflicts of interest, creating obstacles for sharing information. Results and developments are thus rarely publicized, especially in successful profitable ventures, and experiences are rarely shared at local or national levels. This makes it difficult to understand what a successful or unsuccessful CBA is in practice. In addition, many CBA initiatives are implemented at small scale and in geographically isolated sites, where information sharing with other communities and stakeholders may not be practical. Given these challenges, sharing information and consolidating best practices through workshops with experts can be beneficial in gathering knowledge for prioritizing and designing strategies that contribute in overcoming the limitations. This is particularly important given the sparse resources and investment currently available for CBA in the WIO region. The broad spectrum of environmental, cultural, political, and socioeconomic situations across the WIO region, coupled with the existence of CBA initiatives farming diverse species at various stages and scales of development and investment, presents a unique opportunity to share experiences to promote exchange of knowledge. Although complex relationships exist, represented by a varying degree of involvement of local communities in business partnerships and governance, in this paper we focus on the smallscale marine farming whose main goal is diversifying coastal livelihoods and stimulating new employment in addition to provision of necessary protein for local communities. Many of these CBA projects also have a dual goal of promoting biodiversity conservation, either indirectly as a result of reduced dependence on local natural resource and/or directly through creation of new habitats and restoration of degraded areas and supporting marine reserves. They are mainly centered on the production of finfish (mainly milkfish), shellfish (mainly oysters and shrimps), holothurian and seaweed farming. The initial investment required is often small, being practicable at a household to village scale, and rarely reaching the scale seen in commercial aquaculture ventures.

\section{METHODS}

In order to identify and discuss common challenges faced by CBA projects in the WIO and provide recommendations for best practice, a workshop entitled "Community based aquaculture in the Western Indian Ocean: challenges faced and lessons learned" was organized in Zanzibar, Tanzania 9-11 December 2013. A total of 44 individuals participated in the workshop and came from across the WIO: Kenya, Tanzania, Mozambique, South Africa, Madagascar, and Seychelles, as well as international experts from Europe. Considering the complexity of CBA and two main aspects of the workshop, improving existing practice and sharing relevant information, it was vital that participants included not only technical experts and key stakeholders but also a diverse group of participants working in aquaculture and other relevant fields. Participants comprised researchers, technicians and extension workers, commercial partners, CBA farmers, fishers, conservation ecologists, and university students. Prior to the workshop, we conducted a literature review on the development of mariculture in general and CBA in particular in the WIO region, to identify and prioritize key themes of the workshop. To ensure sufficient representation, the call for participation was advertised well in advance and potential participants selected based on review of abstracts of papers submitted for presentation during the workshop. Additional participants were selected following recommendations by experts from the region. The workshop was organized around three sessions that reflected three main objectives: (a) identifying key challenges and social-ecological impacts of CBA in the WIO, (b) evaluating effectiveness of CBA programs in promoting biodiversity conservation, (c) proposing recommendations for dealing with the main challenges, reducing negative impacts and promoting biodiversity conservation.

The workshop had three sessions in accordance with the above three objectives. Participants formed three groups based on the three major CBA activities practiced in the region: (a) finfish, (b) shellfish and invertebrate, and (c) seaweed farming. To maximize interaction, participants were asked to form smaller subgroups and come up with a list of the main challenges faced and their ecological and socioeconomic impacts. Each group was then allowed to present and explain its findings to the main group. Following item-by-item discussion by the latter, a new list was prepared by excluding overlapping items and including new ones that emerged during the discussion. Finally, participants were asked to rate the issues/impacts into low, medium, and high importance points. In session 3, members were asked to propose recommendations for addressing the main challenges facing CBA projects in achieving the two main goals of socioeconomic development of coastal communities and biodiversity conservation.

\section{RESULTS}

Seaweeds (5 species), microscopic algae (2 species), crustaceans ( 8 species), molluscs ( 17 species), sea cucumbers (1 species), finfish (14 species), and a few species of corals and sponges are farmed by WIO coastal communities, mainly for export purposes (Table 1; A teweberhan et al. 2014). Given the dynamic nature and rapidly evolving state of the aquaculture sector in the region (Troell et al. 
2011), this estimated number of species is probably conservative. It is also expected to increase significantly considering the likelihood of introduction of other potential species for commercial purposes.

Table 1. Number of community-based aquaculture (CBA) projects and farmed taxa in four western Indian Ocean countries.

\begin{tabular}{lccccc}
\hline \hline Country & Seaweed & Shellfish & Finfish & $\begin{array}{c}\text { Sea } \\
\text { cucumber }\end{array}$ & Total \\
\hline Kenya & 8 & 9 & 6 & 0 & 23 \\
Madagascar & 23 & 6 & 0 & 7 & 36 \\
Mozambique & 6 & 2 & 0 & 0 & 8 \\
Tanzania & 22 & 22 & 8 & 3 & 55 \\
\hline
\end{tabular}

A small number of species constitute the bulk of the region's production. These are the two red seaweed species (Kappaphycus alvarezii or cottonii and Eucheuma spinsum or spinosum; more than 15 metric tonnes [95\%]) and two shrimp species (Penaeus monodon and Fenneropenaeus indicus; $9.2 \mathrm{mt}$ [4\%; FAO 2011, Troell et al. 2011, Msuya et al. 2014]). Sea cucumber (Holuthuria scabra or sandfish), mud crab (Scilla serrata), and finfish farming are also some of the fast-growing CBA initiatives. Milkfish, mullet (mainly Mugil cephallus), and rabbit fish (Siganus sutor) are the primary farmed fish species. New arrangements involving local communities in the farming of high value species, e.g., abalone (Haliotis midae) in South Africa are also emerging but are not considered in this study because South Africa is likely to represent a different social-ecological system setting owing to its history and development.

Tanzania has the highest number of CBA sites, followed by Madagascar and Kenya (Table 1), while Madagascar ranks the highest both in terms of production and income. Generally, country-level production statistics are presented as a single unit or at best separated between freshwater and coastal and by species or group of species, which makes it difficult to disaggregate data and make comparison among community-based, privately owned, industrial and commercial, extensive, semi-intensive and intensive aquaculture ventures. Nevertheless, sufficient information is available to allow a general analysis of the two most active CBA sectors (seaweed and prawn farming), and the three other fastgrowing sectors (sea cucumber, finfish, and shellfish farming; Table 1). Generally, four CBA models could be recognized in terms of partnerships and involvement of local communities in governance and decision making (Box 1).

\section{Main challenges in CBA}

\section{Biophysical factors}

Many areas in the WIO are suitable for mariculture of finfish and invertebrates. However, shallow locations could be less suitable for the production of Kappaphycus alvarezii (cottonii), the highly demanded seaweed species (Msuya et al. 2014). High surface seawater temperature and irradiation and associated epiphyte and disease infection are increasingly limiting growth of the alga in the shallow lagoonal environments that have traditionally been the favored locations for seaweed farming. Grazing pressure, particularly from algal-feeding rabbit fish and sea urchins is significant as well in limiting seaweed production (Eklöf et al. 2006, Ateweberhan et al. 2015). Shortages of seed and feed material are the main constraints to the production finfish, shellfish, and other invertebrates. Although viral and bacterial infections were observed in some of the finfish and invertebrate CBA farms, no mass mortalities were reported.

Box 1: Characteristics of common types of CBA models practised in the WIO

The basic model commonly comprises at least three partners: local community, local/national government, and an international donor. Although the local community and the donor are the main players, the role of government is often limited in setting policy and provision of technical support through research and extension programs. Often, the international donor is responsible for capacity building of both the local community and research institute. Decisions are often vertical, made by government, without or with little involvement of the local community. The main role of the research and extension institute is providing technical advice and support in governance. Recent shifts in this model include involvement of the local research institute as a business partner. For example, the University of Toliara's Marine Research Institute (IHSM) in Madagascar is a business partner in some of the seaweed and sea cucumber farming projects in the southwest part of the country. It co-owns and manages the local hatchery and provides juveniles to the farms and profits from the sale according to the initial contract signed with the local community and other partners. With community governance becoming a widespread concept, this model is now becoming less common. The second and most common model includes a local or international NGO, whose main role is capacity building of the local community. Depending on the relationship and trust it fosters with the local community, its role could include facilitation of relationship with other partners and support in governance. The third model includes an additional tier in the form of private business partners and industry and is practised mainly in southwest Madagascar and Tanzania. Here the role of the business partner varies from provision of basic equipment, such as plastic ropes to be used in seaweed farming, e.g., Zanzibar, to financing a wide range of research and development aspects of the project, e.g., southwest Madagascar. In the former, farmers are tied down to an agreement to sell dried seaweed to the business partner but are not expected to pay back for the materials provided. In southwest Madagascar, the marine products trading company, Copefrito, is a joint investor with the local community, IHSM, and the aquaculture company, Indian Ocean Trepang (IOT), and a local NGO and partially finances the farming activities and buys products in accordance to contracts negotiated with the local community, which is supported by the local NGO.

\section{Social, organizational / governance challenges}

Western Indian Ocean coastal communities are among the poorest and some of the most underserved communities, as well as within their own countries (Cinner 2009, Cinner 2011). Skills, literacy and education levels are low, and could be vulnerable to serious risks, owing to shifts in weather, health, markets, investment, and public policy (Maina et al. 2008, McClanahan et 
al. 2008, Cinner et al. 2012, Msuya et al. 2014). The infrastructural and institutional assets within and around them are weak (Cinner 2011) and represent some of the major constraints in sustainable CBA development.

Farming site availability is a growing challenge, especially in inshore systems and in finfish production systems where ownership is not clearly identified. Use of suitable sites could be problematic because gaining formal permission is often onerous to the developer, necessitating involvement of different government bodies, e.g., district councils and several government departments or ministries. There is unequal access to resources and marginalization of some community members in many areas in all the countries studied. For example, coastal communities in Madagascar have no formal rights to the marine resources. There is also absence of clear policy frameworks, leading to contradictory messages and lack of procedures to streamline developments or harmonize between and within government departments.

\section{Challenges in building sound business partnerships}

Associated with the lack of adequate infrastructure described above, the communities rarely have adequate financial resources to be able to support their own projects and often depend on governments, development NGOs, and private business partners for finance. They are weakly organized and lack business training, and are unlikely to have a united voice and associated bargaining power with buyers and supply chains, to address unfair or exploitative contracts or prices with commercial partners.

Donor support is often too short term to ensure financial sustainability of CBA initiatives, and thus its viability following termination of funding. Some initiatives also tend to look to donor support as a source of income as opposed to support for the transition. Larger community groups seem to have poor group cohesion and a lack of commitment.

\section{Challenges in accessing global and regional markets}

The poor levels of knowledge and skills and weak financial and organizational capacity described above, create major obstacles in accessing global and regional markets for the development of profitable and sustainable CBA. For example, local business partners have low profit margins in comparison to international buyers who do not invest in the production process and are not bound by agreements. Widely cultured species, such as milkfish and seaweed, are of low value. The seaweed spinosum is easier to grow than cottonii, but has very low global demand and its price is too low to be profitable. These low value species are currently running on low input-low output systems, with little consideration of the value chains, or opportunities to add value to the products. Central economic and fiscal policies also play a significant role in supressing CBA development. For example, Tanzanian seaweed farmers are required to pay tax on sales, placing them in a disadvantaged position relative to some of their counterparts in Southeast Asia that are partially or fully tax exempt. Terms of business partnerships are often unclear and seldom understood by local community partners, leading to regular breach of contracts and agreements by community members as well as commercial partners. This is compounded by weak enforcement of agreements by government.

\section{Ecological and socioeconomic impacts of CBA programs}

\section{Ecological impacts}

Positive ecological impact of CBA has been attributed mainly to increased biodiversity and biomass, habitat improvement, and stock enhancement, resulting from creation of reserves, no take zones, and marine protected areas as source of seed for finfish and shellfish to be used for aquaculture. Many CBA programs in intertidal zones are accompanied by planting of mangrove trees in dykes and pond surroundings, often in areas that were previously deforested mangrove habitats. CBA associated afforestation has resulted in habitat restoration and creation of new habitat through increased mangrove forest cover, and increased diversity of mangrove trees and other species, including birds. Although on a smaller scale, coral and sponge farms also provide habitat for fish and invertebrates.

Stock enhancement in nearby areas due to release of larvae from farms has also been noticed. Similarly, an increase in the number of juveniles and adult fish in the wild due to spill-over effects from farms was suggested, in addition to enhancement of wild populations due to reduced fishing pressure resulting from increased incomes from aquaculture.

Depletion of wild stocks and habitat destruction, introductions of diseases and exotic species, increased genetic risks, and chemical and physical pollution were identified as the main negative ecological impacts. Many of the CBA projects involving finfish and crustacea use juveniles from nearby wild populations, resulting in an observable depletion of wild stocks of target species because of overharvesting, e.g., of crabs, spat, or oysters. The farming of higher trophic level fish, e.g., grouper, and invertebrates, e.g., shrimp, also requires large quantities of wildcaught fish as feed, causing further depletion of wild stocks.

Other negative impacts include reduction of natural biodiversity in some CBA farming areas and nearby habitats due to dominance by farmed species and negative effect on food chain and trophic relations, e.g., due to overpredation by mud crab. Mangrove clearing for shellfish and finfish pond construction and destruction of terrestrial land through pond construction and salinization were also highlighted as key negative impacts.

Farming-associated disturbances like trampling, boat moorings, and deliberate uprooting of benthic organisms can disturb habitat-forming species like seagrasses and seaweed beds, stony corals, and other sessile invertebrates in shallow areas. Additionally, off-bottom seaweed farming requires the use of wooden stakes and pegs that mostly use mangroves, and could contribute to deforestation of nearby mangrove areas and other forested places. Use of natural habitats as grow-out areas, such as seagrass beds and other soft bottom habitats in rearing sea cucumber and other species, could result in habitat alteration by the effects of burrowing of sea cucumbers and habitat destruction by farmers during cage construction, maintenance, and harvesting.

Introduction and assisted growth of large quantities of non-native strains and species, e.g., mussels and oysters, could result in negative environmental impacts through (a) competition with local populations for limiting resources; (b) alteration of trophic interactions; (c) release of potentially toxic substances; (d) increase in suspended particles; (e) change in sediment 
geochemistry; (f) change in nutrient cycling; and (g) changes in benthic and pelagic population dynamics and community structure. For example, successful establishment of Kappaphycus and Eucheuma in Zanzibari waters suggests their potential as ecological invaders (Halling et al. 2013). Diseases introduced through farms could result in depletion of both farmed and unfarmed species, as well as changes in community structure and habitat destruction, e.g., white spot syndrome in wild shrimp populations. It was also indicated that most aquaculture farms start with few individuals as brood stock and have a high risk of inbreeding (Li et al. 2004, Purcell 2012). For instance, sandfish populations have restricted ranges of genetic dispersal or develop local subpopulations (Uthicke and Purcell 2004).

Introduction of nutrients through feed in intensive finfish and shellfish farming could result in chemical pollution from exudates from farmed organisms. Intensive farms, with their use of pesticides, herbicides, and antibiotics to control fouling organisms and diseases could result in chemical pollution and bioresistance. The large number of plastic bottles used as floats in seaweed longlines and rafts could cause physical and chemical pollution. Construction of ponds, dykes, cages, and other structures could result in obstruction of water movement.

\section{Socioeconomic impacts}

Increased income, improved nutrition through consumption of farmed fish, community organization, social integration, and enhanced knowledge, skills, and awareness were the main positive socioeconomic impacts identified. It was reported that increased availability of protein and income from mariculture had resulted in better health conditions and improved social relations, reducing reliance on fishing. For example, milkfish and grey mullet farmed along mangrove dykes in Kenya and Tanzania are used for local consumption while the more expensive mud crab (Scylla serrata) and shrimp are mainly sold to local resorts. Seaweeds and sea cucumbers are mainly used for export purposes, resulting in increased income and probably indirectly in improved nutrition.

Most CBA projects involve women and other members of poor households. Participation of women in CBA was seen as a catalyst for promoting gender empowerment, leading to a greater involvement of women in household decision making, management of finances, and participation in community activities outside the household. Engagement of community members, technicians, and other stakeholders in CBA has enhanced their knowledge and technical skills, not only in marine farming but also in general marine environmental awareness and community based conservation. Involvement of women and other vulnerable groups has also resulted in increased community awareness and motivation about CBA and biodiversity conservation.

Decreased production and low income in some CBA projects, conflict with traditional resource users, and loss of trust were the main negative social-ecological impacts identified. It was noted that the number of women seaweed farmers in Zanzibar has decreased substantially over the past decade because of the lowering production of the high quality seaweed cottonii. The seaweed is sensitive to high seasonal temperatures, which makes it prone to infection by epiphytes and diseases. This is compounded by the comparatively low demand and price of spinosum (Msuya et al. 2007, 2014). Despite the reduced income some community members still continue to practice the unprofitable activity, e.g., women seaweed farmers in Zanzibar, which may lead to other negative socioeconomic impacts, such as poor health condition and deteriorated social relations (Eklöf et al. 2012, Fröcklin et al. 2012).

Increased privatization and expansion of mariculture to common resource areas could limit access to other essential marine resources. This in turn could result in greater user conflict between mariculture practitioners and other resource users, undermining social relations and interfering with conservation. For example, many poor artisanal fishers in geographically isolated areas use particular paths to access shallow fishing sites. Farming plots located in these passageways may hinder access to open fishing areas. In addition, increased theft of high value farmed organisms, e.g., sea cucumbers, has been a constraint to successful production on some CBA efforts, eroding trust and increasing conflict among community members (Rougier et al. 2013, Slater et al. 2014).

\section{Linkage with conservation}

We did not identify a clear link between CBA and marine conservation outcomes in any of the CBA projects because in part of a recognized dearth of evidence-based case studies. Nevertheless, a number of CBA initiatives form a component of wider conservation objectives, with a potential for synergistic benefits for both aquaculture and conservation outcomes. Some of the seaweed and sea cucumber farming projects in southwest Madagascar are an integral component of the Velondriake Local Marine Management Area (LMMA; Harris 2007). Here dozens of community farming groups have been able to diversify their livelihoods within the protected area. Likewise, some projects in Kenya and Tanzania involving milkfish farming are part of mangrove conservation initiatives. These "silvofishery" projects are based on the principle that milkfish farming can improve communities' understanding of mangrove forest management while generating income (Mirera and Ngugi 2009). Milkfish ponds are commonly constructed in the intertidal areas behind the mangrove forests, or in deforested and degraded areas previously covered by mangrove. Fish pond dykes constructed to protect the ponds are then planted with mangrove trees to protect the ponds and provide shade and shelter.

The workshop highlighted the potential of CBA as a tool for enhancing wild stocks of depleted populations. Examples include shellfish, mud crab, sea cucumber, and finfish ranching for reseeding and stock enhancement purposes. In Madagascar's Velondriake LMMA, sea cucumber farms in particular are considered by local communities to contribute toward repopulation of depleted stocks of wild Holothuria scabra populations, as a result of spawning of mature adults within aquaculture pens. Similarly, farming of the pearl oyster Pinctada margaritifera in Zanzibar involves protection of the nearby reef as a no-take zone where pearl oysters could reach mature size and enhance stocks in nearby fished areas (Haws et al. 2010).

\section{DISCUSSION}

The findings of the workshop and knowledge derived from a diverse range of experts and practitioners underline the multifaceted nature of CBA, representing complex interactions involving the biophysical environment, social and institutional setups within which management processes take place. It is 
directly and indirectly influenced by meso- and large-scale environmental and socio-political systems, which could in turn be swayed by global forces. The results also highlight that despite its high potential, development of CBA in the WIO region is still in its infancy and has experienced several setbacks mainly associated with the lack of economic and organizational capacity of coastal communities, challenging environmental conditions, poor project design, and insufficient support both in terms of resources and policy. Therefore, for CBA to be an effective tool for offsetting the feedbacks of social-ecological trap, whether through income generation, provision of protein or contribution to conservation, it needs to be holistic, incorporating the various players and considering the interactions.

In addition to the high level of poverty, the presence of weak institutions has been a key factor in the perennial lock-up of the small-fisheries social-ecological systems in the WIO into an impoverished state (Cinner 2011). The lack of adequate policy and regulations, resulting in poor coordination among institutions, is identified as one of the main stumbling blocks for CBA development (Table 2). Although most countries in the region have recently made significant efforts in the development of legal frameworks and institutions around marine and fisheries management, there has been a marked lack of progress on aquaculture. Even in South Africa, where aquaculture is at a relatively advanced state, policy and legislation address mainly environmental management issues, and fall short of stimulating sectoral growth (Shipton and Hecht 2007). Even where there is a relatively more comprehensive policy, e.g., Mozambique (Ribeiro 2007, FAO 2010) there is no clear evidence on its implementation on the ground. Considering the great potential for regional development of mariculture, addressing the lack of clear policy guidelines and coordination will be crucial for the sustainability of the sector.

Almost all the CBA projects in the WIO are not supported by robust monitoring or reliable documentation of methods, production, or impacts. Thus, the remarks of workshop participants on ecological and socioeconomic impacts could be based on perceptions or observations elsewhere, and are probably subjective. Nevertheless, key trends have emerged and these could serve as valuable pointers to future efforts on scaling-up. Despite the uncertainties described above, most workshop participants strongly believe that CBA has a great potential to grow and be an important vehicle for improving local livelihoods. Presence of good water quality and diverse habitats, and strong willingness of coastal communities to be involved in aquaculture were suggested as key indicators of this potential. The increasing global demand for marine products, particularly for finfish and high value food and ornamental invertebrates (Cai 2011, Troell et al. 2014, Béné et al. 2016) provides a great opportunity for communities to benefit from the ongoing expansion of the broader mariculture sector.

Most of the existing CBA initiatives in the WIO are small scale, requiring low inputs, with low levels of production, and being practiced at household or village level, with probably low negative environmental impacts. They allow considerable participation of local communities, although this is generally limited to manual labor in farm operations. However, despite some increase in the incomes of farming communities, there is no evidence that CBA has resulted in profound transformations of coastal livelihoods. Negative socioeconomic impacts of some CBA types have even been suggested to be related to decreased production and subsequently in income in addition to poor health (Fröcklin et al. 2012). Significant improvements in income and food security may require the introduction of more intensive methods and coverage of larger areas, necessitating a strategic investment in postharvest processing to enable communities to recover more value from product supply chains (Aguilar-Manjarrez et al. 2017). Intensification involving large financial and technological investments will also require more skilled labor that is unavailable at the local level, leading to a more top-down decision process, mainly dominated by the private sector, potentially perpetuating the marginalization of local communities (Páez-Osuna 2001, Bush et al. 2010). This scenario could trigger unwanted positive feedbacks of habitat degradation and deteriorating socioeconomic conditions (Páez-Osuna 2001, Bryceson 2002, Rönnbäck et al. 2002). Broad-based adaptive approaches and partnerships, connecting coastal communities with multisector expertise, from research to production, value-addition and marketing are critical for ensuring sustained community engagement and socioeconomic advancement through CBA (Krause et al. 2015). The emergence of such partnerships will be contingent on measures that recognize local user rights, especially over inshore marine resources (Berkes 2004, Folke et al. 2005) and governance practices (Turner et al. 2014, Krause et al. 2015). The short-term nature of donor financing has been identified as one of the main limitations for the development of sustainable CBA. Consequently, sustained support in particular by donors, and willing private investors and NGOs remains crucial for promoting capacity of local communities, national and local institutions. To avoid negative experiences related to power imbalance in terms of financial and human resources and information, there is a need to identify an optimum mix of partners that are willing to engage in open and transparent communication, which must be preceded by a detailed needs assessment (Newell et al. 2012). The collaboration of the University of Toliara's Marine Science Institute (IHSM), a local seafood exporter Copefrito, the aquaculture company Indian Ocean Trepang (IOT), and a local NGO Blue Ventures Conservation has been crucial for the viability of CBA projects in southwest Madagascar (see Box 1).

The absence of a clear link between aquaculture and conservation in many of the CBA projects is probably due to divergent objectives of the two sectors; goals of mariculture in the region rarely go beyond income generation and provision of additional protein. Only a handful of CBA projects were designed and implemented as an integral part of biodiversity conservation. However, it is difficult to ascertain effectiveness of these because there is no systematic gathering of data on key indicators, especially the social and human behavioral drivers underpinning decision making and environmental impacts (Vincent and Morrison-Saunders 2013). One potential cause for the ineffectiveness could be that low value species, e.g., seaweed and milkfish, may be unable to make up for overharvested populations, contributing less to alleviation of fishing pressure, highlighting the need for more consideration of species that could contribute to reduction in overharvesting and improvement of ecosystem services (Froehlich et al. 2017). In addition to the information gap on ecological and socioeconomic impacts, the 
Table 2. Issues limiting effectiveness of community-based aquaculture (CBA) and proposed recommendations.

\begin{tabular}{ll}
\hline \hline Step & Key issue and rationale for action \\
\hline Developing & Most coastal communities involved in CBA in the \\
community capacity & $\begin{array}{l}\text { western Indian Ocean (WIO) region are not only } \\
\text { and improving }\end{array}$ \\
financially poor, they also have low levels of education \\
and technical skills and production systems \\
characterized by weak level of organization to achieve \\
maximum production. They lack access to financial \\
services and are unable to participate effectively in \\
business partnerships and other decisions to maximize \\
profitability.
\end{tabular}

Increasing seed and Shortages of seed and feed were some of the main feed supply in finfish, issues identified as constraining the development of shellfish, and invertebrate farming
Improving growth conditions and marketing of low value species
Although seaweed farming is a low input system, the highly demanded species Kappaphycus alvarezii (cottonii) is harder to grow than the less sought after Eucheuma denticulatum (spinosum). Many shallow sites are unsuitable for cottoni farming because of high water temperatures and associated epiphyte and disease infections. These infections are expected to increase with climate change.

Some of the taxa that are relatively easier to grow have low market values, notably milkfish (Chanos chanos) and Eucheuma spp. Value addition to these and other products will not only result in increased prices and incomes for communities but could also increase participation by communities, building their understanding of markets and their bargaining power.
Minimizing negative environmental and social impacts of CBA
Habitat destruction, disease and species introductions, overharvesting of juveniles and adults from the wild, and increased pollution were the main negative ecological impacts of CBA identified. Negative social impacts identified included the introduction of unsustainable practices (e.g., mangrove deforestation and overharvesting of juveniles from the wild), privatization of traditionally commonly owned coastal areas and declining profits, health, and social relations (e.g., seaweed farming in Zanzibar).

Integrating CBA into The presence of healthy natural ecosystems such as conservation programs coral reefs, seagrass meadows, and mangrove forests increases the value of coastal and marine fisheries, by increasing productivity and supporting a wide biological diversity.

Except for a few cases, there was no evidence of clear integration between CBA and biodiversity conservation.
Recommendations

Commit further investment toward improved production.

Develop strategies and dedicate investment toward reinforcing the decisionmaking authority of coastal communities in order to improve their participation within national aquaculture planning frameworks, in particular forming business partnerships with private investors.

Build hatcheries and develop the necessary technical skills in representative areas. This should also be accompanied with a sustainable supply of feed for larvae, juveniles, and adults.

Develop sound business partnerships between communities, commercial partners, and research institutions for promoting research in the development of hatcheries and feed processing plants.

Develop techniques for growing cottonii in deeper waters where it is cooler and conditions are more stable in addition to identification and cultivation of other profitable species.

Promote value addition to taxa that are relatively easier to grow but have low market values, notably milkfish and spinosum. These and other products will not only result in increased prices and incomes for communities but could also increase participation by communities, building their understanding of markets and their bargaining power.

Introduce higher value species and develop cooperative bargaining platforms to counter price fixing in markets, and revision of existing import-export and tax policies by governments.

Develop value addition through sound business partnerships between community and commercial partners, supported by clearly stipulated agreements and regulations.

Develop research on introduction of high value species and accessing wider markets.

Promote good governance structures and principles for effective decision making and to build trust among those involved in different parts of the value chain.

Minimize impacts through stringent regulatory guidelines addressing environmental and social issues, including conducting social-ecological impact assessments before starting new projects. Aquaculture development must also adapt to the needs and capacities of communities. Planning for these can be enhanced with appropriate application of models needed to clearly predict whether the socioeconomic benefits of aquaculture are reconcilable with potential environmental costs among others.

Promote effective integration of CBA projects into conservation and development programs at all stages from planning to implementation, and monitor and evaluate in a participatory way, involving local communities and other key partners. This should be supported by legal policy frameworks developed to ensure transparency and accountability. There is also a need for institutional coordination to avoid conflicting messages coming from different government departments. recognition of an absence of adequate policy supporting mariculture underscores the need for the re-evaluating of the sector against the initial and new objectives (Costa-Pierce 2010,
Krause et al. 2015). Identifying and monitoring key sustainability indicators through community participation will be the first step in achieving that goal. 


\section{CONCLUSIONS}

Whether intended for the sole purpose of income generation or biodiversity conservation, development of CBA in the WIO will be dependent on sustained capacity building of communities, along with coordinated integration of activities by stakeholders. This can be achieved through partnerships in business, research, and supply chains, accompanied by supportive policy and regulatory regimes to create an enabling environment for CBA to become a viable economic pathway for marine resource dependent coastal communities. Most of the existing CBA initiatives in the region are low input-output and highly dependent on nearby natural resources, creating even stronger demands for an integrated marine resource management approach. Where the goals of CBA are biodiversity conservation, their full integration into community-based conservation programs is essential for promoting the safeguarding and long-term sustainability of the vital resource base. Where income generation is the main goal, with biodiversity conservation as an indirect result, application of high value species and intensive approaches might be required. Limiting the reinforcement of existing feedbacks of socialecological trap becomes essential for safeguarding the future of local communities.

Responses to this article can be read online at: http://www.ecologyandsociety.org/issues/responses. $\mathrm{php} / 10411$

\section{Acknowledgments:}

Financial support to organize the workshop was provided by the Western Indian Ocean Marine Science Association (WIOMSA) through its Marine Science for Management (MASMA) program. We are grateful to Blue Ventures Conservation and the Zanzibar Institute of Marine Science and University of Dar-Es-Salaam for administrative support, and to 10 technical experts from the region for reviewing abstracts presented by participants of the workshop.

\section{LITERATURE CITED}

Aguilar-Manjarrez, J., D. Soto, and R. Brummett. 2017. Aquaculture zoning, site selection and area management under the ecosystem approach to aquaculture. Report ACS113536. Food and Agriculture Organization, Rome, Italy, and World Bank Group, Washington, D.C., USA.

Allison, E. H. 2011. Aquaculture, fisheries, poverty and food security. Working paper 2011-65. Commissioned for OECD. Worldfish Centre, Penang, Malaysia.

Anderson, W., and S. A. Saidi. 2011. Internationalization and poverty alleviation: practical evidence from Amani Butterfly Project in Tanzania. Journal of Poverty Alleviation and International Development 2:17-45.

Ateweberhan, M., J. Hudson, A. Rougier, A. Harris, N. Jiddawi, and F. E. Msuya. 2014. Community based aquaculture in the western Indian Ocean: challenges faced and lessons learned. Blue Ventures Conservation. London, UK.
Ateweberhan, M., A. Rougier, and C. Rakotomahazo. 2015. Influence of environmental factors and farming technique on growth and health of farmed Kappaphycus alvarezii (cottonii) in south-west Madagascar. Journal of Applied Phycology 27:923-934. http://dx.doi.org/10.1007/s10811-014-0378-3

Barnes-Mauthe, M., K. L. L. Oleson, and B. Zafindrasilivonona. 2013. The total economic value of small-scale fisheries with a characterization of post-landing trends: an application in Madagascar with global relevance. Fisheries Research 147:175-185. http://dx.doi.org/10.1016/i.fishres.2013.05.011

Béné, C., R. Arthur, H. Norbury, E. H. Allison, M. Beveridge, S. Bush, L. Campling, W. Leschen, D. Little, D. Squires, S. H. Thilsted, M. Troell, and M. Williams. 2016. Contribution of fisheries and aquaculture to food security and poverty reduction: assessing the current evidence. World Development 79:177-196. http://dx.doi.org/10.1016/j.worlddev.2015.11.007

Berkes, F. 2004. Rethinking community-based conservation. Conservation Biology 18:621-630. http://dx.doi.org/10.1111/ j.1523-1739.2004.00077.x

Beveridge, M. C. M., S. H. Thilsted, M. J. Phillips, M. Metian, M. Troell, and S. J. Hall. 2013. Meeting the food and nutrition needs of the poor: the role of fish and the opportunities and challenges emerging from the rise of aquaculture. Journal of Fish Biology 83:1067-1084. http://dx.doi.org/10.1111/jfb.12187

Bradshaw, C. J. A., and B. W. Brook. 2014. Human population reduction is not a quick fix for environmental problems. Proceedings of the National Academy of Sciences 111:16610-16615. http://dx.doi.org/10.1073/pnas.1410465111

Brummett, R. E., J. Lazard, and J. Moehl. 2008. African aquaculture: realizing the potential. Food Policy 33:371-385. http://dx.doi.org/10.1016/j.foodpol.2008.01.005

Bryceson, I. 2002. Coastal aquaculture developments in Tanzania: sustainable and non-sustainable experiences. Western Indian Ocean Journal of Marine Science 1(1):1-10.

Bush, S. R., P. A. M. van Zwieten, L. Visser, H. Van Dijk, R. Bosma, W. F. De Boer, and M. Verdegem. 2010. Scenarios for resilient shrimp aquaculture in tropical coastal areas. Ecology and Society 15(2):15. http://dx.doi.org/10.5751/ES-03331-150215

Cai, J. 2011. Preliminary notes on forecasting country's future demand for fish. FAO Aquaculture Newsletter 47:16-17.

Christensen, J. H., B. Hewitson, A. Busuioc, A. Chen, X. Gao, I. Held, R. Jones, R. K. Kolli, W.-T. Kwon, R. Laprise, V. Magaña Rueda, L. Mearns, C. G. Menéndez, J. Räisänen, A. Rinke, A. Sarr, and P. Whetton. 2007. Regional climate projections. Pages 847-940 in S. Solomon, D. Qin, M. Manning, Z. Chen, M. Marquis, K. B. Averyt, M. Tignor, and H. L. Miller, editors. Climate change 2007: the physical science basis. Contribution of Working Group I to the Fourth Assessment Report of the Intergovernmental Panel on Climate Change. Cambridge University Press, Cambridge, UK.

Cinner, J. E. 2009. Poverty and the use of destructive fishing gear near East African marine protected areas. Environmental Conservation 36:321-326. http://dx.doi.org/10.1017/S0376892910000123 
Cinner, J. E. 2011. Social-ecological traps in reef fisheries. Global Environmental Change 21:835-839. http://dx.doi.org/10.1016/j. gloenvcha.2011.04.012

Cinner, J. E., T. R. McClanahan, N. A. J. Graham, T. M. Daw, J. Maina, S. M. Stead, A. Wamukota, K. Brown, and Ö. Bodin. 2012. Vulnerability of coastal communities to key impacts of climate change on coral reef fisheries. Global Environmental Change 22:12-20. http://dx.doi.org/10.1016/j.gloenvcha.2011.09.018

Costa-Pierce, B. A. 2010. Sustainable ecological aquaculture systems: the need for a new social contract for aquaculture development. Marine Technology Society Journal 44:88-112. http://dx.doi.org/10.4031/MTSJ.44.3.3

Dadzie, S. 1992. An overview of aquaculture in Eastern Africa. Hydrobiologia 232:99-110. http://dx.doi.org/10.1007/BF00014618

Diana, J. S. 2009. Aquaculture production and biodiversity conservation. Bioscience 59:27-38. http://dx.doi.org/10.1525/ bio.2009.59.1.7

Eklöf, J. S., R. Henriksson, and N. Kautsky. 2006. Effects of tropical open-water seaweed farming on seagrass ecosystem structure and function. Marine Ecology Progress Series 325:73-84. http://dx.doi.org/10.3354/meps325073

Eklöf, J. S., F. E. Msuya, T. J. Lyimo, and A. S. Buriyo. 2012. Seaweed farming in Chwaka Bay: a sustainable alternative in aquaculture? Pages 213-233 in M. de la Torre-Castro and T.J. Lyimo, editors. People, nature and research in Chwaka Bay. WIOMSA, Zanzibar, Tanzania.

Eriksson, H., G. Robinson. M. Slater, and M. Troell. 2012. Sea cucumber aquaculture in the Western Indian Ocean: challenges for sustainable livelihood and stock improvement. $A M B I O$ 41:109-121. http://dx.doi.org/10.1007/s13280-011-0195-8

Folke, C., T. Hahn, P. Olsson, and J. Norberg. 2005. Adaptive governance of social-ecological systems. Annual Review of Environmental Resources 30:441-473. http://dx.doi.org/10.1146/ annurev.energy.30.050504.144511

Food and Agriculture Organization (FAO). 2010. National aquaculture sector overview: Mozambique. FAO, Rome, Italy.

Food and Agriculture Organization (FAO). 2011. Review of the state of world marine fisheries. FAO, Rome, Italy.

Froehlich, H. E., R. R. Gentry, and B. S. Halpern. 2017. Conservation aquaculture: shifting the narrative and paradigm of aquaculture's role in resource management. Biological Conservation 215:162-168. http://dx.doi.org/10.1016/j.biocon.2017.09.012

Fröcklin, S., M. de la Torre-Castro, L. Lindström, N. S. Jiddawi, and F. E. Msuya. 2012. Seaweed mariculture as a development project in Zanzibar, East Africa: a price too high to pay? Aquaculture 356-357:30-39. http://dx.doi.org/10.1016/j. aquaculture.2012.05.039

Gentry, R. R., H. E. Froehlich, D. Grimm, P. Kareiva, M. Parke, M. Rust, S. D. Gaines, and B. S. Halpern. 2017. Mapping the global potential for marine aquaculture. Nature Ecology \& Evolution 1:1317-1324. http://dx.doi.org/10.1038/s41559-017-0257-9

Gonzales, E. M., U. K. Maung Soe, R. Mukherjee, S. H. Nguyen, A. Suspita, J. M. Wattoo, and P. Bulcock. 2006. Regional review on livelihood opportunities related to mariculture development. Pages 65-94 in A. Lovatelli, M. J. Phillips, J. R. Arthur, K. Yamamoto, editors. FAO/NACA Regional Workshop on the future of mariculture: a regional approach for responsible development of mariculture in the Asia-Pacific region, Guangzhou, China, 7-77 March.

Halling, C., S. A. Wikström, G. Lilliesköd-Sjöö, E. Mörk, E. Lundsør, and G. C. Zuccarello. 2013. Introduction of Asian strains and low genetic variation in farmed seaweeds: indications for new management practices. Journal of Applied Phycology 25:89-95. http://dx.doi.org/10.1007/s10811-012-9842-0

Harris, A. 2007. "To live with the sea" - development of the Velondriake community-managed protected area network, southwest Madagascar. Madagascar Conservation \& Development 2:43-49. http://dx.doi.org/10.4314/mcd.v2i1.44129

Harris, A., G. Manahira, A. Sheppard, C. Gough, and C. Sheppard. 2010. Demise of Madagascar's once great barrier reef: change in coral reef condition over 40 years. Atoll Research Bulletin 574:1-18. http://dx.doi.org/10.5479/si.00775630.574.16

Haws, M., B. Crawford, M. C. Portella, S. Ellis, N. Jiddawi, A. Mmochi, E. Gaxiola-Camacho, G. Rodriguez-Dominguez, G. Rodriguez, J. Francis, et al. 2010. Aquaculture research and development as an entry-point and contributor to natural resources and coastal management. Coastal Management 38:238-261. http://dx.doi.org/10.1080/08920753.2010.483168

Ireland, C., D. Malleret, and L. Baker. 2004. Alternative sustainable livelihoods for coastal communities: a review of experience and guide to best practice. International Union for Conservation of Nature and Natural Resources, Eastern Africa Regional Programme, Nairobi, Kenya.

Krause, G. C. Brugere, A. Diedrich, M. W. Ebeling, S. C. A. Ferse, E. Mikkelsen, J. A. P. Agúndez, S. M. Stead, N. Stybel, and M. Troell. 2015. A revolution without people? Closing the peoplepolicy gap in aquaculture development. Aquaculture 447:44-55. http://dx.doi.org/10.1016/j.aquaculture.2015.02.009

Li, Q., C. Park, T. Endo, and A. Kijima. 2004. Loss of genetic variation at microsatellite loci in hatchery strains of the Pacific abalone (Haliotis discus hannai). Aquaculture 235:207-222. http:// dx.doi.org/10.1016/j.aquaculture.2003.12.018

Little, D. C., B. K. Barman, B. Belton, M. C. Beveridge, S. J. Bush, L. Dabaddie, H. Demaine, P. Edwards, M. M. Haque, and G. Kibria. 2012. Alleviating poverty through aquaculture: progress, opportunities and improvements. Pages 719-783 in Proceedings of the Global Conference of Aquaculture 2010: Farming the Waters for People and Food, 22-25 September.

Loper, C., R. Pomeroy, V. Hoon, P. McConney, M. Pena, A. Sanders, G. Sriskanthan, S. Vergara, M. Pido, R. Vave, C. Vieux, and I. Wanyonyi. 2008. Socioeconomic conditions along the world's tropical coasts. National Oceanic and Atmospheric Administration, Global Coral Reef Monitoring Network, and Conservation International, Arlington, Virginia, USA.

Maina, J., V. Venus, T. R. McClanahan, and M. Ateweberhan. 2008. Modelling susceptibility of coral reefs to environmental stress using remote sensing data and GIS models. Ecological Modelling 212:180-199. http://dx.doi.org/10.1016/j.ecolmodel.2007.10.033 
McClanahan, T. R., M. Ateweberhan, C. A. Muhando, J. Maina, and M. S. Mohammed. 2007. Effects of climate and seawater temperature variation on coral bleaching and mortality. Ecological Monographs 77:503-525. http://dx.doi.org/10.1890/06-1182.1

McClanahan, T. R. , J. E. Cinner, J. Maina, N. A. J. Graham, T. M. Daw, S. M. Stead, A. Wamukota, K. Brown, M. Ateweberhan, V. Venus, and N. V. C. Polunin. 2008. Conservation action in a changing climate. Conservation Letters 1:53-59. http://dx.doi. org/10.1111/j.1755-263X.2008.00008 1.X

Mirera, D. H. O., and C. C. Ngugi. 2009. Sustainability and income opportunities of farming milkfish (Chanos chanos) to local communities in Kenya: assessment of initial trials of earthen ponds. SARNISSA Report. Kenya Marine and Fisheries Research Institute (KMFRI), Mombasa, Kenya.

Mirera, D. H. O., and M. A. Samoilys. 2008. Natural resource dependence, livelihoods and development: mariculture exchange between Kenya and Tanzania. IUCN ESARO, Nairobi, Kenya.

Msuya, F. E., A. Buriyo, I. Omar, B. Pascal, K. Narrain, J. J. M. Ravina, E. Mrabu, and J. G. Wakibia. 2014. Cultivation and utilisation of red seaweeds in the western Indian Ocean (WIO) region. Journal of Applied Phycology 26:699-705. http://dx.doi. org/10.1007/s10811-013-0086-4

Msuya, F. E., M. S. Shalli, K. Sullivan, B. Crawford, J. Tobey, and A. J. Mmochi. 2007. A comparative economic analysis of two seaweed farming methods in Tanzania. The Sustainable Coastal Communities and Ecosystems Program. Coastal Resources Center, University of Rhode Island, USA, and the Western Indian Ocean Marine Science Association, Zanzibar, Tanzania.

Newell, P., P. Pattberg, and H. Schroeder. 2012. Multifactor governance and the environment. Annual Review of the Environment and Resources 37:365-387. http://dx.doi.org/10.1146/ annurev-environ-020911-094659

Páez-Osuna, F. 2001. The environmental impact of shrimp aquaculture: causes, effects, and mitigating alternatives. Environmental Management 28:131-140. http://dx.doi.org/10.1007/ $\underline{\mathrm{s} 002670010212}$

Purcell, S.W. 2012. Principles and science of stocking marine areas with sea cucumbers. Asia-Pacific Tropical Sea Cucumber Aquaculture. ACIAR Proceedings 136:92-103.

Ribeiro, F. 2007. Inventory of small-scale mariculture in Mozambique. The Sustainable Coastal Communities and Ecosystems (SUCCESS) Program. WIOMSA, Zanzibar, Tanzania.

Rice, M. A., A. J. Mmochi, L. Zubieri, and R. M. Savoie. 2006. Aquaculture in Tanzania. World Aquaculture 37:50-57.

Rönnbäck, P., I. Bryceson, and N. Kautsky. 2002. Coastal aquaculture development in Eastern Africa and the western Indian Ocean: prospects and problems for food security and local economies. AMBIO 31:537-542 http://dx.doi.org/10.1579/0044-7447-31.7.537

Rougier, A, M. Ateweberhan, and A. Harris. 2013. Strategies for improving survivorship of hatchery-reared juvenile Holothuria scabra in community-managed sea cucumber farms. Beche-deMeer 33:14-22.
Shipton, T., and T. Hecht. 2007. Coastal mariculture assessment mission final report. Regional Programme for the Sustainable Management of the Coastal Zones of the Indian Ocean Countries (ReCoMaP), Victoria, Seychelles.

Shoko, A., M. Lamtane, K. Wetengere, O. Kajitanus, F. Msuya, A. Mmochi, and Y. Mgaya. 2011. The status and development of aquaculture in Tanzania, East Africa. Pages 85-97 in P. Natarajan, L. Wondimu, T. Boyossa, M. I. Zuberi, A. S. Nair, A. Beyeh, and E. Aga, editors. Technical Proceedings of the International Conference on Ecosystem Conservation and Sustainable Development (ECOCASD 2011). Ambo University, Ambo, Ethiopia, 10-12, February.

Slater, M. J., Y. D. Mgaya, A. C. Mill, S. P. Rushton, and S. M. Stead. 2013. Effect of social and economic drivers on choosing aquaculture as a coastal livelihood. Ocean and Coastal Management 73:22-30. http://dx.doi.org/10.1016/j.

ocecoaman.2012.12.002

Slater, M. J., Y. D. Mgaya, and S. M. Stead. 2014. Perceptions of rule-breaking related to marine ecosystem health. PLOS ONE 9 (2):e89156. http://dx.doi.org/10.1371/journal.pone.0089156

Troell, M., T. Hecht, M. Beveridge, S. Stead, I. Bryceson, N. Kautsky, A. Mmochi, and F. Ollevier. 2011. Mariculture in the WIO region - challenges and prospects. Book Series 11. WIOMSA, Zanzibar, Tanzania.

Troell, M., R. L. Naylor, M. Metian, M. Beveridge, P. H. Tyedmers, C. Folke, K. J. Arrow, S. Barrett, A. S. Crépin, P. R. Ehrlich, et al. 2014. Does aquaculture add resilience to the global food system? Proceedings of the National Academy of Sciences 111:13257-13263. http://dx.doi.org/10.1073/pnas.1404067111

Turner, R. A., C. Fitzsimmons, J. Forster, R. Mahon, A. Peterson, and S. M. Stead. 2014. Measuring good governance for complex ecosystems: perceptions of coral reef-dependent communities in the Caribbean. Global Environmental Change 29:105-117. http:// dx.doi.org/10.1016/j.gloenvcha.2014.08.004

Uthicke, S., and S. Purcell. 2004. Preservation of genetic diversity in restocking of the sea cucumber Holothuria scabra investigated by allozyme electrophoresis. Canadian Journal of Fisheries and Aquatic Sciences 61:519-528. http://dx.doi.org/10.1139/f04-013

Van der Elst, R., B. Everett, N. Jiddawi, G. Mwatha, P. S. Afonso, and D. Boulle. 2005. Fish, fishers and fisheries of the Western Indian Ocean: their diversity and status. A preliminary assessment. Philosophical Transactions of the Royal Society A: Mathematical, Physical and Engineering Sciences 363:263-284. http://dx.doi.org/10.1098/rsta.2004.1492

Vincent, I. V., and A. Morrison-Saunders 2013. Applying sustainability thinking to a community-governed development: a sea cucumber farm in Madagascar. Impact Assessment and Project Appraisal 31:208-213. http://dx.doi.org/10.1080/14615517.2013.773720 